\title{
Grammar and Grammaring: Toward Modes for English Grammar Teaching in China
}

\author{
Chengyu $\mathrm{Nan}^{1}$ \\ ${ }^{1}$ School of Foreign Languages, Yanbian University, Jilin, China \\ Correspondence: Chengyu Nan, School of Foreign Languages, Yanbian University, Jilin, 133000, China. Tel: \\ 0086-433-2436895. E-mail: cynan@ybu.edu.cn
}

Received: October 15, 2015 Accepted: November 10, 2015 Online Published: November 12, 2015

doi:10.5539/elt.v8n12p79

URL: http://dx.doi.org/10.5539/elt.v8n12p79

\begin{abstract}
The value of grammar instruction in foreign language learning and teaching has been a focus of debate for quite some time, which has resulted in different views on grammar and grammar teaching as well as different teaching approaches based on different perspectives or in different language learning contexts. To explore some modes for grammar teaching in China on the basis of distinguishing grammar and grammaring, this research reviews briefly the current situations of grammar teaching at colleges in China and the various teaching modes adopted in different teaching contexts. Two teaching modes are suggested, linguistic mode and story-telling mode, which may activate inquiry learning and active learning. Linguistic mode, which emphasizes the dual features of grammar learning, is more reasoning-centered than knowledge-centered and is designed from linguistic and academic perspective for advanced learners. Story telling mode, which focuses on smooth communication in different contexts, is more skill-centered than rule-centered and is designed from social and communicative perspective for beginners. Exploring the modes for teaching grammar from linguistic and social perspectives will be a pilot study for inquiring other aspects of grammar teaching as well as for teaching grammar to the learners of other languages.
\end{abstract}

Keywords: grammar, grammaring, grammar teaching, linguistic mode, story telling mode

\section{Introduction}

As one component of communicative competence (Canale \& Swain, 1980), grammar is one of the essential elements of language learning and teaching. Despite the significant changes in approaches to language teaching that have occurred in recent years, the status of grammar instruction is an issue that language teachers still have to resolve (Ellis, 2002). According to our survey from 2013 to 2014, grammar is still taught in most of the English departments in China as a compulsory course called English Grammar, Practical English Grammar, or English Grammar and Writing. A Handbook of English Grammar by Bao Bing was used as a textbook in the 1980s, Practical English Grammar by Zhang Daozhen was used in the 1990s and A New English Grammar Course Book by Zhang Zhenbang or Basic English Grammar, Fundamentals of English Grammar and Understanding and Using English Grammar by Betty Schramfer Azar have been used since the 21st century. Since most of the exercises in these textbooks are mechanical rather than meaningful or synthetic, more explicit and deductive grammar teaching is conducted than inductive or guided discovery teaching with more focus on form and meaning than use.

This research makes a brief review of grammar teaching in China and abroad and then tries to explore the modes for grammar teaching in China on the basis of distinguishing grammar and grammaring.

\section{Overview of Grammar and Grammar Teaching}

\subsection{Role of Grammar Teaching}

There are many different views on the role of grammar and grammar teaching in foreign language teaching since the issue is looked at from different perspectives or in different language learning contexts.

A lot of research has agreed that there is a positive role of grammar teaching in foreign language learning. Celce-Murcia (1991) held that grammar instruction is part of language teaching since grammar interacts with meaning, social function, or discourse — or a combination of these - rather than standing alone as an autonomous system to be learned for its own sake. That is to say, grammatical competence is essential for communication 
(Brown, 1994; Larsen-Freeman \& Long, 1991) and instructed learners are found to outperform uninstructed learners in their rate of learning and level of achievement (Long, 1988). Hinkel and Fotos (2002) argued that grammar teaching can enhance learner proficiency and accuracy and facilitate the internalization of its syntactic system. Designing tasks and curriculum that built on what learners already know represents one of the strengths of explicit grammar teaching within the format of communicative and interactional activities. Other scholars argued that teaching grammar should not be banned and grammar instruction should be carried out in a way that does not interfere with natural acquisition (Long, 1991). Explicit attention to grammatical form can contribute to spontaneous production as well (Housen, Pierrard \& Van Daele, 2005; Sheen, 2005; Pawlak, 2007; Spada \& Tomita, 2010; Scheffler, 2012). Scott (1989) drew the similar conclusion about explicit attention in his empirical study that explicitly instructed students outperformed in a grammar test than implicitly instructed ones.

But, according to Larsen-Freeman (2015), some scholars think grammar teaching has little value for natural language acquisition process (Krashen, 1981; Paradis, 2004) and learning grammar rules and practicing them are only of marginal value (Krashen, 1999, 2011) because it would not develop learners' grammatical competence.

\subsection{Grammar Teaching in Different Contexts}

Grammar teaching has experienced different teaching contents and approaches from The Grammar-Translation Method, The Direct Method, The Audio-Lingual Method, The Cognitive Method to The Communicative Approach. Scholars put forward Grammar Consciousness Raising Approach (Rutherford, 1987; Rutherford \& Smith, 1988; Fotos, 1993), Interactional Feedback Approach (Lyster \& Ranta, 1997; Mackey \& Oliver, 2002), Textual Enhancement Teaching (Donghty \& Varela, 1998), Textual Teaching or Discourse-based Teaching Mode (Hughes \& MaCarthy, 1998; Carter, Hughes, \& McCarthy, 2000; Celce-Murcia, 1990; Celce-Murcia \& Olshtain, 2000), Processing Instruction Approach (VanPatten, 1996, 2002), Task-based Grammar Teaching (Fotos \& Ellis, 1991; Dekeyser, 1998; Eliis, 2003), Interpretation-based Grammar Teaching (Ellis, 1993), Output Tasks Communicative Teaching (Swain, 2000), Story-based Approach (Adair-Hauck, Donato, \& Cumo-Johanssen, 2000), Content-based Teaching (Schneider, 2005), etc. Pennington (2002) proposes a synthesis approach to grammatical pedagogy which emphasizes 4C-collocational, constructive, contextual and contrastive. Richards and Reppen (2014) proposed twelve principles as the basis for a pedagogy that focuses on acquiring learning to use grammar in texts. Larsen-Freeman $(2003,2015)$ recommended grammaring approach which fosters the ability of students to go beyond the input, for, after all, language learning is not about conformity to uniformity.

Chinese scholars adopted Dictogloss Mode (Gao, 1998), Integrating Grammar Instruction (Zhao, 1999), Cognitive Grammar Teaching (Huang, 2002; Lin \& Jia, 2015), Task-based Mode (Zhang \& Sun, 2009; Dai \& Chen, 2005; Dai \& Ren, 2006), etc. Cheng (2013) insisted on context and textual grammar teaching in China. Zhang (2011) talked about the idea of teaching grammar through a content-based approach, Liu (2012) proposed the integration of explicit and implicit strategies for English grammar teaching under Content-based Instruction and Nan (2015, in press) proved teaching multilingual students English grammar under Content-based Instruction is a highly effective means of developing students' multilingual proficiency.

\section{Grammar and Grammaring}

Knowing grammar is not enough for real communication, but an inadequate knowledge of grammar would severely constrain one's capacity for effective communication. Grammar is a lexicogrammatical resource for making meaning. In the process of making meaning, grammar changes in both form and meaning to ensure appropriate use in different situations.

Grammaring was first put forward by Larsen-Freeman in 1992. She regards English grammar not only as a set of structural patterns, but also as an important resource for making meaning and for adapting language appropriately to the communicative context. The grammar system is not closed, but is rather constantly evolving, due to the creativity of its users as they make new meanings, making it impossible to distinguish errors from linguistic innovations without an appeal to sociopolitical factors, such as who is doing the talking (Larsen-Freeman, 2012, 2014b).

According to grammaring, grammar has features of duality to English majors, that is, it should be taken both as knowledge and as ability. When viewed as knowledge, the focus is on the acquisition and research of rules for sentence formation. When viewed as ability, the focus is on how grammar is used as a resource in the creation of spoken and written texts. (Richards \& Reppen, 2014)

\section{Modes for Teaching Grammar}

Different teaching modes, such as a separate mode, an integrated mode, skills mode or knowledge mode, can be 
adopted depending on certain variables in the language teaching contexts, such as leaner variables and instructional variables. This article will suggest two kinds of modes, story-telling mode for beginners and linguistic mode for advanced learners.

\subsection{Linguistic Mode}

Larsen-Freeman $(2002,2014 a)$ maintained that students need to know about the use of structures so that they understand the consequences of their choices since the grammatical system offers its users choices in how they wish to realize meanings and position themselves ideologically and socially. Therefore, grammar teaching should take place not only for understanding the rules but also for inducing the reasons of different sentence formations in different contexts.

English is rich in passive voice which is not possible in many of the other languages with similar passive formation, therefore it is very important for the learners to understand its different meanings in order for appropriate use. Since English passive voice can be used without referring to the agent of an action, the following three functions of passive voice are listed in most grammar books:

- to place emphasis on the agent, using by-phrase

- when the agent is unknown or unimportant

- the speaker does not wish to mention the agent

Usually some exercises of distinguishing active voice and passive voice are designed for the learners according to the three functions. In fact, more exercises which needs explanations in terms of linguistics can be designed and carried out in the classroom teaching. For example, asking the students to analyze the differences among A1, $\mathrm{A} 2$ and $\mathrm{A} 3$ in the following dialogue and explain the reasons or the purposes of Speaker A in answering in different ways.

A: I won't go to the party.

B: Why?

A1: You haven't invited me.

A2: Nobody has invited me.

A3: I haven't been invited.

A1 is the most direct way of answering which expresses complaint to the listener B, and A2 is moderate but still expresses a kind of dissatisfaction, while A3 is a mild way which shows politeness. Being taught in this way, the learners will not only internalize the rules and functions but also inquiry the use of English passive voice. They will realize that choices of different forms of grammar can express various feelings and bring different communicative effects. In addition, since English passive voice is culturally related, the process of reasoning may also contribute to the learners' cross-cultural consciousness raising and their understanding of different worldviews and different ways that speakers of other languages construct experience in the world. (Larsen-Freeman, 2003)

Another example is teaching coordinate construction in English. It is very easy for the students to use and as a conjunction, but not easy for them to know how to use it for a pragmatic effect. Learners are usually taught that and should be used before the last component when it is used to coordinate more than three components. But in fact this rule can be violated for a specific reason.

a. Mary bought a skirt, a shirt, a coat and a handbag.

b. Mary bought a skirt and $a$ shirt and a coat and $a$ handbag.

Sentence $a$ only tells us a fact, but Sentence $b$ entails more than that. When and is used between all the noun phrases instead of being used only between the last two, it not only functions as connecting two coordinate structures but also embodies some emotional effect and rhetorical effect. This kind of grammar instruction enables the students to integrate form, meaning and use of grammar. In addition, it will motivate the learners to use grammar in a more flexible way since they know grammar is dynamic and changeable as stated below:

There is a fundamental different between the laws of physics and the laws of language. The law of gravity is not modified by use: no matter how many times we throw a ball into the air, it will fall to the ground with the same acceleration. Rules of grammar, on the other hand, are modified by use. (Haimen, 1985)

Linguistic mode emphasizes more reasoning and inquiring the pragmatics of grammar than understanding the form and meaning. It starts with a certain use of grammar and ends with more uses in different contexts. Its 
circular process is the perfect combination of form, meaning and use and can be formulated as "general use $\rightarrow$ specific use $\rightarrow$ reasoning $\rightarrow$ different meanings $\rightarrow$ forms $\rightarrow$ other uses".

\subsection{Story Telling Mode}

A grammar lesson is not complete without an application stage. Ur (1988) emphasizes that application is believed to require "volume and repetition"; that is, learners need to be given adequate opportunities to use the items to be learnt as much as possible. Therefore, teachers should help learners make the leap from form-focused accuracy to meaning-focused fluency after explicit instructions by providing a variety of practice activities that will familiarize the learners with structure in contexts, giving practice both in form and communicative meaning. (Ur, 1996) Story telling mode is an effective way to apply what the students learn to real communication. English grammar can be taught in real communication through four language skills by listening, speaking, reading and writing some stories of both the teacher and the students. Therefore, it is also called integrated mode.

Sometimes it is difficult for the students, especially beginners, to use simple past and present perfect appropriately. Teaching English grammar to beginners by telling stories can help the students to better understand and use the tense and aspect more correctly. Firstly, we can ask the students to listen to our own stories, for example My Love for Sports, and ask them to recognize different tenses and then answer some related questions. Then the following reading material can be provided for the students to understand the form and meaning of simple past and present perfect.

I'm an English teacher at YBU. I've taught English for more than 28 years. I've taught reading, listening, writing, grammar, linguistics and etc. In order to make my teaching more effective and more interesting, I got my MA in 1999 and Ph.D in 2007. I got a lot of fresh ideas about teaching when I was working in Australia and USA. I love teaching and I love my students.

After listening and reading, the students can be asked to have a free talk about their hobbies and learning experiences in small groups. In this way, they will be highly motivated to learn by hearing more stories which they might be or must be interested in. After class, they will be assigned to write down their own stories. It is more than grammar learning. It is grammaring, that is, applying a rule to produce a grammatical utterance. Students will get to know each other better by telling and listening to each other's stories.

In this way each grammatical structure is introduced in a meaningful context and follow-up communicative interactions are provided to serve as culminating activities that combine meaning, form and use. This mode is a circular process of "use in certain context $\rightarrow$ meaning $\rightarrow$ form $\rightarrow$ other meanings $\rightarrow$ more contexts".

\section{Conclusion}

Perhaps there will never be a solution to the debate about the value of teaching grammar because language learning and teaching contexts vary so greatly. Chinese learners learning a foreign language as a major need a certain degree of mastery of grammar of the target language though learning grammar is not the ultimate goal of leaning a foreign language. Therefore it is important to reform and adjust teaching contents and methods according to different teaching contexts, such as levels of students and linguistics backgrounds of the students.

Grammar can be taught both as knowledge and skills. Teaching grammar as knowledge, linguistic teaching mode emphasizes the dual features of grammar learning, understanding grammar rules and doing research of implicit grammar functions. This mode will empower the English learners with the potential and enthusiasm for inquiry learning and active learning. Story-telling teaching mode can not only provide rich materials for grammar teaching but also motivate students and facilitate their meaningful learning of English grammar as well as smooth communication in different contexts.

Exploring the modes for teaching grammar from linguistic and social perspectives will be a pilot study for researching from other perspectives as well as for teaching grammar to the learners of other languages.

\section{Acknowledgements}

This research was granted by Jilin Province as an Educational Science Project (GH12025) with the topic of Reform and Practice in Grammar Teaching Under Foreign Language Education in China.

\section{References}

Adair-Hauck, B., Donato, R., \& Cumo-Johanssen, P. (2000). Using story-based approach to teach grammar. In J. Shrum, \& E. Glisan (Eds.), Teacher's handbook: Contextualized language instruction ( $2^{\text {nd }}$ ed.). Boston: Heinle \& Heinle.

Brown, H. D. (1994). Principles of Language Learning and Teaching. Englewood Cliffs: Prentice Hall, Inc. 
Canale, M., \& Swain, M. (1980). Theoretical bases of communicative approaches to second language teaching and testing. Applied Linguistics, 1(1), 1-47. http://dx.doi.org/10.1093/applin/i.1.1

Carter, R., Hughes, R., \& McCarthy, M. (2000). Exploring Grammar in Context. Cambridge: Cambridge University Press.

Celce-Murcia, M. (1990). Discourse analysis and grammar instruction. Annual Review of Applied Linguistics, 11, 135-151. Cambridge: Cambridge University Press. http://dx.doi.org/10.1017/s0267190500002002.

Celce-Murcia, M. (1991). Grammar pedagogy in second and foreign language teaching. TESOL Quarterly, 25(3), 459-480. http://dx.doi.org/10.2307/3586980

Celce-Murcia, M., \& Olshtain, E. (2000). Discourse and context in language teaching. Cambridge: Cambridge University Press.

Cheng, X. (2013). Some Thoughts on the Issues in English Grammar Teaching. Curriculum, Teaching Material and Methods, 33(4), 62-70.

Dai, W., \& Chen, L. (2005). A review of L2 grammar teaching theories. Foreign Language teaching and Research, 37(2), 92-99.

Dai, W., \& Ren, Q. (2006). New perspective for grammar teaching: explicit consciousness-raising task modal. Foreign Language World, 111(1), 7-15.

DeKeyser, R. (1998). Beyond focus on form: Cognitive perspectives on learning and practicing second language grammar. In C. Doughty, \& J. Williams (Eds.), Focus on form in classroom second language acquisition (pp. 42-63). Cambridge: Cambridge University Press.

Doughty, C., \& Varela, E. (1998). Communicative focus on forms. In C. Doughty, \& J. Williams (Eds.), Foreign Language Research in Cross-cultural Perspective. Amsterdam: John Benjamins.

Ellis, N. (2002) Frequency effects in language processing: A review with implications for theories of implicit and explicit language acquisition. Studies in Second Language Acquisition, 24(2), 143-188. http://dx.doi.org/10.1017/s0272263102002024.

Ellis, R. (1993). Interpretation-based grammar teaching. System, 21(1), 69-78. http://dx.doi.org/10.1016/0346-251x(93)90007-4

Ellis, R. (2003). Task-based language learning and teaching. Oxford: Oxford University Press.

Fotos, S., \& Ellis, R. (1991). Communicating about grammar: a task-based approach. TESOL Quarterly, 25(4), 605-628. http://dx.doi.org/10.2307/3587079.

Fotos, S. (1993). Consciousness raising and noticing through focus on form: Grammar task performance versus formal instruction. Applied Linguistics, 14(4), 385- 407. http://dx.doi.org/10.1093/applin/14.4.385

Gao, X. (1998). Dictogloss in grammar teaching. Foreign Language World, 70(2), 32-36.

Haimen, J. (1985). Natural syntax. Iconicity and erosion. Cambridge and New York: Cambridge University Press.

Hinkel, E., \& Fotos, S. (Eds.) (2002). New perspectives on grammar teaching in second language classrooms. Mahwah, New Jersey: Lawrence Erlbaum Associates, Inc.

Housen, A., Pierrard, M., \& Van Daele, S. (2005). Rule complexity and the efficacy of explicit grammar instruction. In A. Housen, \& M. Pierrard (Eds.), Investigation in instructed language acquisition (pp. 235-269). Amsterdam: Mouton de Gruyter. http://dx.doi.org/10.1515/9783110197372

Huang, H. (2002). Cognitive approach to English grammar teaching. Foreign Languages and Their Teaching, 155(2), 30-34.

Hughes, R., \& McCarthy, M. (1998). From sentence to discourse: Discourse grammar and English language teaching. TESOL Quarterly, 32(2), 263-287. http://dx.doi.org/10.2307/3587584

Krashen, S. (1981). Second language acquisition and second language learning. Oxford: Pergamon.

Krashen, S. (1999). Seeking a role for grammar: A review of some recent studies. Foreign Language Annals, 32(2), 245-254. http://dx.doi.org/10.1111/j.1944-9720.1999.tb02395.x

Krashen, S. (2011). Seeking a justification for skill-building. KOTESOL Proceedings, 13-20.

Larsen-Freeman, D., \& Long, M. H (1991). An introduction to second language acquisition research. London: 
Longman.

Larsen-Freeman, D. (1992). A nonhierarchical relationship between grammar and communication. Part 1. In J. Alatis (Ed.), Georgetown University round table on language and linguistics 1992 (pp. 158-165). Washington, DC: Georgetown University Press.

Larsen-Freeman, D. (2002). The grammar of choice. In E. Hinkel, \& S. Fotos (Eds.), New perspectives on grammar teaching in second language classrooms (pp. 103-118). Mahwah, NJ: Lawrence Erlbaum.

Larsen-Freeman, D. (2003). Teaching language: from grammar to grammaring. Boston: Heinle\& Heinle.

Larsen-Freeman, D. (2012). The emancipation of the language learner. Studies in Second Language Learning and Teaching, 2(3), 297-309.

Larsen Larsen-Freeman, D. (2014a). Teaching grammar. In M. Celce-Murcia, D. M. Brinton, \& M. A. Snow (Eds.), Teaching English as a second or foreign language (4th ed.) (pp. 256-270). Boston, MA: Heinle/Cengage Learning.

Larsen-Freeman, D. (2014b). Interlanguage: Another step to be taken. In Z.-H. Han, \& E. Tarone (Eds.), Interlanguage 40 years later (pp. 203-220). Amsterdam: Benjamins. http://dx.doi.org/10.1075/1ltt.39.11ch9

Larsen-Freeman, D. (2015). Research into practice: Grammar learning and teaching. Language Teaching, 48(2), 263-280. http://dx.doi.org/10.1017/s0261444814000408.

Lin, Z. \& Jia, L. (2015). A probe into English grammar teaching innovation. Foreign Language Learning Theory and Practice, 3(3), 57-62.

Liu, X. (2012). Grammar teaching strategies in content-based English teaching. Theory and Practice of Contemporary Education, 4(3), 84-86.

Long. M. H. (1988). Instructed interlanguage development. In L. Beebe (Ed.), Issues in Second Language Acquisition: Multiple perspectives. New York: Newbury House.

Long, M. H. (1991). Focus on form: A design feature in language teaching methodology. In K. de Bot, R. Ginsberg, \& C. Kramsch (Eds.), Foreign language research in cross-cultural perspective (pp. 39-52). Amsterdam: Benjamins. http://dx.doi.org/10.1075/sibil.2.07lon

Lyster, R., \& Ranta, L. (1997). Corrective feedback and learner uptake: negotiation of form in communicative $\begin{array}{lllll}\text { classrooms. Studies in Second Language Acquisition, } & \text { 19(1), }\end{array}$ http://dx.doi.org/10.1017/s0272263197001034

Mackey, A., \& Oliver, R. (2002). Interactional feedback and children's L2 development. System, 30(4), 459-477. http://dx.doi.org/10.1016/s0346-251x(02)00049-0.

Nan, C. (2015). Content-Based Instruction: Teaching English Grammar to Multilingual Learners at University. TEAL Monitoba, 30(3) (In press).

Nunan, D. (1998). Teaching grammar in context. ELT Journal, 52(2), 101-109. http://dx.doi.org/10.1093/elt/52.2.101.

Paradis, M. (2004). A neurolinguistic theory of bilingualism. Amsterdam: Benjamins. http://dx.doi.org/10.1075/sibil.18

Pawlak, M. (2007). Comparing the effect of focus on form and focus on forms in teaching English third conditional. In M. Pawlak (Ed.), Exploring focus on form in language teaching (pp. 5-26). Poznan-Kalisz: Adam Mickiewicz University.

Pennington, M. (2002). Grammar and communication: new directions in theory and practice. In E. Hinkel, \& S. Fotos (Eds.), New perspectives on grammar teaching in second language classrooms (pp. 77-98). Mahwah, New Jersey: Lawrence Erlbaum Associates, Inc.

Richards, J. C., \& Reppen, R. (2014). Towards a Pedagogy of Grammar Instruction. RELC Journal, 45(1), 5-25. http://dx.doi.org/10.1177/0033688214522622

Rutherford, W. E. (1987). Second language grammar: learning and teaching. New York: Longman. http://dx.doi.org/10.4324/9781315835914

Rutherford, W. E., \& Sharwood, S. (1988). Grammar and second language teaching: A book of readings. New York: Newbury House.

Schneider. J. (2005). Teaching grammar through community issues. ELT Journal, 59(4), 298-305. 
http://dx.doi.org/10.1093/elt/cci058

Scott, V. M. (1989). An empirical study of explicit and implicit teaching strategies in French. Modern Language Journal, 73(1), 14-22. http://dx.doi.org/10.2307/327262.

Sheen, R. (2005). Focus on forms as a means of improving accurate oral production. In A. Housen, \& M. Pierrard (Eds.), Investigations in instructed second language acquisition (pp. 271-310). Amsterdam: Mouton de Gruyter. http://dx.doi.org/10.1515/9783110197372.2.271

Scheffler, P. (2012). Theories pass. Learners and teachers remain. Applied Linguistics, 33(5), 603-607. http://dx.doi.org/10.1093/applin/ams062

Spada, N., \& Tomita, Y. (2010). Interactions between type of instruction and type of language feature: A meta-analysis. Language Learning, 60(2), 263-308. http://dx.doi.org/10.1111/j.1467-9922.2010.00562.x

Swain, M. (2000). The output hypothesis and beyond: Mediating acquisition through collaborative dialogue. In J. P. Lantolf (Ed.), Sociocultural Theory and Second Language Learning. Oxford: Oxford University Press.

Ur, P. (1988). Grammar practice activities: A practical guide for teachers. Cambridge: Cambridge University Press.

Ur, P. (1996). A course in language teaching: practice and theory. Cambridge: Cambridge University Press.

VanPatten, B. (1996). Input processing and grammar instruction in second language acquisition. Norwwod, NJ: Ablex Publishing Corporation.

VanPatten, B. (2002). Processing instruction: An update. Language Learning, 52(4), 755-803. http://dx.doi.org/10.1111/1467-9922.00203

Zhang, P., \& Sun, J. (2009). Teaching English grammar through tasks. Foreign Languages and Their Teaching, 246(9), 36-42.

Zhang, Y. (2011). Content-based instruction in grammar teaching of English majors. Journal of Taiyuan Normal University, 10(5), 155-157.

Zhao, M. (1999). Teaching grammar to English majors. Foreign Language World, 76(4), 49-52.

\section{Copyrights}

Copyright for this article is retained by the author(s), with first publication rights granted to the journal.

This is an open-access article distributed under the terms and conditions of the Creative Commons Attribution license (http://creativecommons.org/licenses/by/3.0/). 